UNDERGRADUATE RESEARCH IN NATURAL AND CLINICAL SCIENCE AND TECHNOLOGY (URNCST) JOURNAL Read more URNCST Journal articles and submit your own today at: https://www.urncst.com

\title{
The Effects of Personalized Music Listening on Older Adults with Dementia: A Literature Review
}

\author{
Chethana N. Ellewela, BSc Student [1]*, Monica Yuen, BSc Student [2] \\ [1] Department of Biochemistry and Biomedical Sciences, McMaster University, \\ Hamilton, Ontario, L8S 4L8 \\ [2] Department of Biology, McMaster University, Hamilton, Ontario, L8S 4L8 \\ *Corresponding Author: ellewelc@mcmaster.ca
}

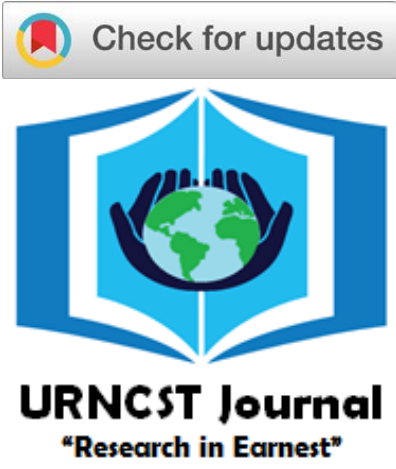

\begin{abstract}
Introduction: Dementia affects millions of people globally and can impact the emotional and cognitive well-being of these individuals. Interventions such as music therapy, including the use of personalized music, are increasingly being used to help reduce the severity of symptoms and enhance patient care. Research has shown that music is strongly associated with longterm memory, and the use of familiar songs may trigger emotional arousal and past memories in individuals with dementia. However, the effectiveness of listening to personalized music on alleviating dementia symptoms is unclear. The aim of this review was to examine the effects of listening to personalized music on emotional arousal and mood in individuals with dementia.

Methods: Two databases, Embase and PubMed, were searched for articles exploring personalized or preferred music listening in older adults with dementia and were screened by two co-authors.

Results: A total of 9 studies were included in the review. Five of the included studies found positive impacts on mood, such as increased happiness. Two studies demonstrated decreases in agitation, and two studies demonstrated decreases in anxiety.

Discussion: This review found an overall positive impact of listening to personalized music on emotion and behavioural and psychological symptoms in dementia (BPSD). The improved emotional arousal and mood shown in this review may lead to enhanced motivation during cognitive tasks, ultimately improving overall performance.

Conclusion: Although listening to personalized music was found to strengthen emotional affect and mood, there are inconsistencies in the parameters used during musical interventions. Thus, it is evident that further research is required to determine the optimal guidelines for implementing personalized music listening interventions.
\end{abstract}

Keywords: dementia; music; personalized music; arousal; mood; cognition; emotion

\section{Introduction}

Dementia is a neurodegenerative condition characterized by a progressive decline in cognitive function and affects factors such as comprehension, memory, and language [1]. As of 2020, an estimated 50 million people around the world are diagnosed with dementia, with symptoms including memory loss and impairments in communication and daily functioning [1]. There are various forms of dementia such as vascular dementia and dementia with Lewy bodies, with the most common form being dementia due to Alzheimer's disease (AD) [1]. While there is currently no cure for dementia, various interventions are being explored to improve the quality of life of people living with this disorder, and alleviating the burden for caregivers and loved ones [1]. One such intervention involves the use of music in therapeutic practices for people with dementia [2].

Research has demonstrated evidence of beneficial outcomes following musical interventions in individuals with dementia. A well-known anecdote of this occurred in
1932, where French music composer Maurice Ravel suffered head injuries following a car accident [2]. He was tentatively diagnosed with a progressive neurodegenerative disease as he began to experience greater symptoms of cognitive decline [2]. While Ravel struggled with reading, writing, and speaking, he was able to recognize and identify changes and errors in his music [2]. Since then, preliminary research has suggested that musical abilities can remain intact following injuries to the brain or in those with neurological disorders [3]. Currently, various projects and programs explore the benefits of music in the treatment of those with neurological disorders, including dementia. The Music and Memory iPod Program, a project by the Alzheimer Society, provides iPods to individuals with dementia that contain personalized playlists [4]. An evaluation of the Alzheimer Society of Toronto conducted by the Balance of Care Research and Evaluation Group found that this low-cost intervention has demonstrated benefits such as improvements in the quality of life in people with dementia, and encouraged the spread and use 
UNDERGRADUATE RESEARCH IN NATURAL AND CLINICAL SCIENCE AND TECHNOLOGY (URNCST) JOURNAL Read more URNCST Journal articles and submit your own today at: https://www.urncst.com

of the iPod Program [5]. However, the mechanisms underlying how personalized music provides such benefits to people with dementia remain unclear.

Theories and models underlying the general cognitive benefits of music have been mixed in nature. One popular belief is that listening to music by itself can make one smarter. The "Mozart effect" is a finding that suggests enhanced performance in spatial tasks in healthy, young adults after listening to music written by Mozart [6]. However, this belief has been overgeneralized to include all cognitive abilities and limited the scope to Mozart's music. More recent research, such as a study by Thompson et al., suggested that the improved cognitive abilities from the supposed "Mozart effect" may in fact be due to changes in emotional arousal or mood from listening to enjoyable music [6]. The arousal-and-mood hypothesis states that listening to music can influence the arousal and mood of an individual, causing greater motivation during cognitive performances [6]. Emotional arousal is defined as changes in affective states, which can be measured by physiological indices such as heart rate and respiration [7]. More recent models have proposed the strength of using musical interventions in neurodegeneration, such as the Therapeutic Music Capacities Model (TMCM) [8]. The TMCM is an evidence-based framework that identifies components of music that can be targeted to create individualized musicbased interventions. According to TMCM, music can be manipulated and applied specifically to be engaging, emotional, physical, personal, social, persuasive, and affording synchronization of movement [8]. This modern theory outlines the neurological and psychological mechanisms behind the benefits provided by music, particularly personalized music, in order to support those with neurodegenerative disorders [8].

Despite the abundant literature pertaining to music therapy, the effects of personalized music listening in people with dementia strongly vary. There is no consensus as to the mechanisms of the benefits of personalized music, and no agreement in the implementation and measurement of the effects and outcomes of music-based interventions. Therefore, the aim of this paper is to review the literature surrounding the effects of personalized music listening on emotional arousal and how this may affect cognitive performance in adults with dementia.

\section{Methods}

A literature review was conducted using two electronic databases: Embase and PubMed. A search strategy using the terms "music" AND ("cognition" OR "emotion") AND "dementia" was used. In total, 910 articles were obtained from both databases. Article screening was conducted by two independent reviewers (i.e., co-authors). Each author was blind to the other's assessments of article suitability. Relevant articles were screened and filtered using inclusion and exclusion criteria. The articles included were English peer-reviewed studies that analyzed an outcome concerning emotion or cognition following a personalized musical listening intervention in older adults with various types of dementia. The exclusion criteria consisted of review articles, studies that did not examine passive music listening, and studies without an outcome measure concerning either cognition or emotional arousal.

Following screening, the authors found 9 articles that fit the criteria, which were further analyzed for data extraction. The data extracted included the demographics of the population (such as age range, sample size, and dementia subtype), intervention methodology, primary outcome measures, and results.

\section{Results}

The search resulted in nine full-text articles which exhibited improvements in mood, anxiety and agitation following listening to personalized music. Tables 1 and 2 summarize the demographics and findings from each article.

\section{Overall Improvement in Positive Affect}

Personalized music was demonstrated to have a positive effect on mood in five of the studies. In the study conducted by Buller et al., 190 participants were given iPods with personalized playlists consisting of 15 to 30 songs, and listened to the playlists for 20 to 30 minutes daily [9]. Caregivers filled out surveys assessing mood changes due to music listening. The study found that $78 \%$ of participants reported improved overall mood as well as increased happiness [9]. In a similar study, Murphy et al.

examined the impact of preferred music on mood in participants with unspecified dementia [10]. iPods were distributed with personalized playlists, which were modified and updated on a bi-weekly basis. Individuals who listened to personalized music reported improvements in mood and quality of life as well [10].

Sakamoto, Ando, and Tsutou conducted a study investigating the effects of individualized music in 39 individuals with $\mathrm{AD}$ [11]. Participants were equally divided into control, passive, and interactive groups. This intervention lasted 30 minutes, once a week for 10 weeks. Participants in the interactive group listened to personalized music accompanied by a facilitator, while the passive group listened to personalized music without the facilitator [11]. The control group sat in a room with an observer in silence. Although the interactive group saw improvements in a larger number of items in the Behavioural Pathology in Alzheimer's Disease (BEHAVE-AD) scale compared to the passive group, participants in the passive group demonstrated dominant parasympathetic nerve activity (as revealed by slower heart rate) and a shift to more comfortable moods [11]. 
UNDERGRADUATE RESEARCH IN NATURAL AND CLINICAL SCIENCE AND TECHNOLOGY (URNCST) JOURNAL Read more URNCST Journal articles and submit your own today at: https://www.urncst.com

Table 1. Summary of results obtained from literature search.

\begin{tabular}{|c|c|c|c|c|}
\hline $\begin{array}{l}\text { Author(s) / } \\
\text { Year }\end{array}$ & Demographics & Intervention & Primary Outcomes & Results \\
\hline $\begin{array}{l}\text { Pilar Pérez- } \\
\text { Ros et al. } \\
(2019)\end{array}$ & $\begin{array}{l}\text { - } \mathrm{n}=119, \text { age } 65+ \\
\text { - Unspecified } \\
\text { dementia }\end{array}$ & $\begin{array}{l}\mathrm{n}=72 \text { in control } \\
\text { group; } \mathrm{n}=47 \text { in } \\
\text { intervention } \\
\text { group } 5 \mathrm{x} \text { per week } \\
\text { for } 8 \text { weeks }\end{array}$ & $\begin{array}{l}\text { Functional } \\
\text { independence, } \\
\text { emotional affect, Mini } \\
\text { Mental State } \\
\text { Examination (MMSE) }\end{array}$ & $\begin{array}{l}\text {-Lower MMSE scores in } \\
\text { control group over time; } \\
\text { intervention group remained } \\
\text { stable } \\
\text {-Increased depression in } \\
\text { control group over time; scores } \\
\text { in intervention group remained } \\
\text { stable }\end{array}$ \\
\hline $\begin{array}{l}\text { Buller et al. } \\
(2019)\end{array}$ & $\begin{array}{l}\text { - } \mathrm{n}=190, \text { age } 50 \mathrm{~s}-90 \mathrm{~s} \\
\text { - Unspecified } \\
\text { dementia }\end{array}$ & $\begin{array}{l}\text { Personalized } \\
\text { playlists were } \\
\text { distributed via } \\
\text { iPods }\end{array}$ & $\begin{array}{l}\text { Caregivers rated effects } \\
\text { of music on participant } \\
\text { mood, and functional } \\
\text { independence }\end{array}$ & $\begin{array}{l}-78 \% \text { of participants reported } \\
\text { improved mood } \\
\text { - others reported increased } \\
\text { happiness, and decreased } \\
\text { anxiety and depression }\end{array}$ \\
\hline $\begin{array}{l}\text { Murphy et } \\
\text { al. (2018) }\end{array}$ & $\begin{array}{l}\text { - } \mathrm{n} 35, \\
\text { - Unspecified } \\
\text { dementia }\end{array}$ & $\begin{array}{l}\text { iPods distributed } \\
\text { with preferred } \\
\text { music playlists }\end{array}$ & $\begin{array}{l}\text { Survey examining } \\
\text { mood changes and } \\
\text { benefits of personalized } \\
\text { music }\end{array}$ & $\begin{array}{l}\text { Participants who had normal or } \\
\text { withdrawn moods showed } \\
\text { improvements in mood, } \\
\text { demonstrated reductions in } \\
\text { negative behaviour and } \\
\text { improved quality of life }\end{array}$ \\
\hline $\begin{array}{l}\text { Sakamoto, } \\
\text { Ando, and } \\
\text { Tsutou } \\
(2013)\end{array}$ & $\begin{array}{l}-\mathrm{n}=39, \text { age } 65+ \\
-\mathrm{AD}\end{array}$ & $\begin{array}{l}\text { - } \mathrm{n}=13 \text { in each of } \\
\text { control group - } \\
\text { passive group } \\
\text { (personalized music } \\
\text { listening) } \\
\text {-interactive group } \\
\text { (listening + active } \\
\text { participation) } \\
\text { - } 10 \text { weeks }\end{array}$ & $\begin{array}{l}\text { - Physiological, BPSD } \\
\text { ratings, and facial } \\
\text { recordings as indices of } \\
\text { emotional arousal }\end{array}$ & $\begin{array}{l}\text { - passive group: dominant } \\
\text { parasympathetic nerve activity, } \\
\text { more comfortable mood, } \\
\text { reduced affective disturbance } \\
\text { and anxieties/phobias } \\
\text { - control group: increased } \\
\text { affective disturbances }\end{array}$ \\
\hline
\end{tabular}

Reschke-Hernandez et al. explored the influence of familiar music on emotion in individuals with AD [12]. Participants were asked to select 10 examples of music that had a positive impact on their emotions and 10 that had a negative impact. Based on this information, two personalized playlists (i.e., music induction sets) were created for each participant that were approximately 4.5 minutes long [12]. Participants were asked to rate their emotions after listening to the music induction sets. They were then asked to recall the songs they previously listened to and rate their emotions once again. Participants reported feeling substantially happier following the positive music set and sadder following the negative music set [12]. In addition, participants also reported lingering sad or happy feelings according to the survey conducted 20 minutes post-intervention. The authors concluded that familiar music can have a substantial impact on the emotional well-being in individuals with $\mathrm{AD}$ [12].

Garrido et al. explored the impact of individualized playlists on those with various dementias, including AD and vascular dementia [13]. Participants and/or caregivers were asked to complete a questionnaire regarding musical preferences, which was used to create a personalized playlist. Participants were then subjected to 30-minute listening sessions. FaceReader (i.e. software used to recognize facial emotion) was used to measure sadness, and significant increases in sadness were seen in those with high levels of depression [13]. However, those with high apathy and low depression showed high levels of pleasure during the intervention. The study also found that participants with greater cognitive impairment experienced lower levels of pleasure throughout the intervention [13].

Dementia-Associated Behaviours and Emotions

Studies have examined the impacts of preferencebased musical interventions on alleviating negative behaviours and emotions associated with dementia. Buller et al. used the distribution of iPods containing personalized playlists to examine effects on various symptoms of dementia. Following the intervention, the study found that participants reported decreased anxiety and depression [9]. Similarly, Murphy et al. also administered personalized playlists through the use of iPods, and this intervention resulted in reduced negative behaviours such as agitation and refusal [10]. 
UNDERGRADUATE RESEARCH IN NATURAL AND CLINICAL SCIENCE AND TECHNOLOGY (URNCST) JOURNAL Read more URNCST Journal articles and submit your own today at: https://www.urncst.com

A study by Pérez-Ros et al. examined preferred music listening in 119 participants with unspecified dementia and 72 controls [14]. The control group received standard occupational therapy while the intervention group listened to preferred music of their choice for 60 minutes five times a week for two weeks in addition to the standard occupational therapy. The control group demonstrated an increase in depression scores, assessed using the Yesavage Scale, while the experimental group had stable scores over time [14]. Further, using the Mini Mental State Examination (MMSE, a cognitive tool for assessing dementia), a decline in cognitive status was seen over time in the control group, but no change in the dementia group, indicating a maintenance of cognitive status associated with music listening [14].

Table 2. Summary of results obtained from literature search.

\begin{tabular}{|c|c|c|c|c|}
\hline $\begin{array}{l}\text { Author (s) / } \\
\text { Year }\end{array}$ & Demographics & Intervention & Primary Outcomes & Results \\
\hline $\begin{array}{l}\text { Ragneskog } \\
\text { et al. }(2001)\end{array}$ & $\begin{array}{l}\text { - } \mathrm{n}=4 \text {, age } 77-84 \\
-\mathrm{AD} \text { and vascular } \\
\text { dementia }\end{array}$ & $\begin{array}{l}\text { All participants sat } \\
\text { in silence, and } \\
\text { listened to Pachelbel } \\
\text { music and } \\
\text { individualized music }\end{array}$ & $\begin{array}{l}\text { Video recordings via } \\
\text { Facial Action Coding } \\
\text { System }\end{array}$ & $\begin{array}{l}\text { Personalized music reduced } \\
\text { agitation in two of the four } \\
\text { patients (with less severe } \\
\text { dementia) compared to silence }\end{array}$ \\
\hline $\begin{array}{l}\text { Reschke- } \\
\text { Hernández et } \\
\text { al. (2020) }\end{array}$ & $\begin{array}{l}-n=20 \text {, age } 64-89 \\
-A D\end{array}$ & $\begin{array}{l}\text { Participants listened } \\
\text { to individualized } \\
\text { lists of happy and } \\
\text { sad music }\end{array}$ & $\begin{array}{l}\text { Emotion was assessed } \\
\text { using three self- } \\
\text { reporting scales }\end{array}$ & $\begin{array}{l}\text { Participants reported feeling } \\
\text { happier following happy music } \\
\text { and more sad following sad } \\
\text { music }\end{array}$ \\
\hline $\begin{array}{l}\text { Garrido et al. } \\
\text { (2018) }\end{array}$ & $\begin{array}{l}\text { - } \mathrm{n}=99,63-99 \text { years } \\
\text { old } \\
\text { - AD, vascular } \\
\text { dementia, alcohol- } \\
\text { induced dementia, } \\
\text { Korsakoff's disease }\end{array}$ & $\begin{array}{l}\text { 30-minute sessions } \\
\text { of listening to } \\
\text { preferred music }\end{array}$ & $\begin{array}{l}\text { Affective responses via } \\
\text { facial video recordings; } \\
\text { biometric measures of } \\
\text { arousal, activation of } \\
\text { facial muscles }\end{array}$ & $\begin{array}{l}\text { Following listening, those with } \\
\text { high apathy and low depression } \\
\text { showed evidence of pleasure; } \\
\text { those with high levels of } \\
\text { depression showed more facial } \\
\text { expressions of sadness }\end{array}$ \\
\hline $\begin{array}{l}\text { Sung, } \\
\text { Chang, and } \\
\text { Lee (2010) }\end{array}$ & $\begin{array}{l}\text { - } \mathrm{n}=52 \text {, age } 65+ \\
\text { - Unspecified } \\
\text { dementia }\end{array}$ & $\begin{array}{l}\text { Experimental group } \\
\text { listened to preferred } \\
\text { music ( } 6 \text { weeks) }\end{array}$ & $\begin{array}{l}\text { Anxiety measured using } \\
\text { Rating Anxiety in } \\
\text { Dementia (RAID) tool }\end{array}$ & $\begin{array}{l}\text { Anxiety measured using Rating } \\
\text { Anxiety in Dementia (RAID) } \\
\text { tool }\end{array}$ \\
\hline Park (2013) & $\begin{array}{l}-\mathrm{n}=26, \text { mean age }= \\
82.2 \text { years } \\
\text { - Unspecified } \\
\text { dementia }\end{array}$ & $\begin{array}{l}\text { Individualized } \\
\text { music was } \\
\text { administered for } 30 \\
\text { minutes before peak } \\
\text { agitation time, 2x a } \\
\text { week for } 2 \text { weeks }\end{array}$ & $\begin{array}{l}\text { Peak agitation time and } \\
\text { agitation level }\end{array}$ & $\begin{array}{l}\text { Agitation significantly } \\
\text { decreased during and after } \\
\text { listening to individualized } \\
\text { music }\end{array}$ \\
\hline
\end{tabular}

The study by Sakamoto, Ando and Tsutou further explored the use of personalized music by examining its effects on behavioural and psychological symptoms in dementia (BPSD) [12]. The interactive group demonstrated reductions in affective disturbances, anxiety, and phobias, measured using the autonomic nerve index and the Faces Scale [11]. In the weeks following the end of these interventions, there was a significant increase in BPSD within the passive and active groups, demonstrating the effectiveness of the interventions in alleviating mood disturbances in dementia in the short term [11].

A study by Ragneskog et al. assessed the effects of personalized music on agitation in four adults with either $\mathrm{AD}$ or vascular dementia [15]. Participants were observed via video recordings during their day-to-day behaviours throughout 69 sessions divided into four periods, with the first being a control period where participants were observed with no music, followed by a second period where the same music was played for all the participants. Finally, personalized music was played for both the third and fourth periods. The video recordings of the sessions were taken using Facial Action Coding System (FACS) to measure and classify facial movement [15]. Reduced negative behaviours, such as yelling and screaming, shown in this study suggests that individualized music may reduce agitation in people with dementia and can be considered soothing and relaxing [15].

A study conducted by Sung, Chang, and Lee demonstrated the positive impacts of preferred music on anxiety in individuals with dementia [16]. A control group was subjected to general standard care at nursing homes, whereas the intervention group was administered 30 minutes of preferred music listening in addition to standard care twice a week for a total of 12 sessions [16]. Anxiety 
UNDERGRADUATE RESEARCH IN NATURAL AND CLINICAL SCIENCE AND TECHNOLOGY (URNCST) JOURNAL Read more URNCST Journal articles and submit your own today at: https://www.urncst.com

levels were measured using the Rating Anxiety in Dementia (RAID) tool. The results of the study demonstrated a significant reduction in anxiety levels in the intervention group, with a decrease in mean anxiety ratings [16]. The control group had a slight decrease in anxiety, however it was not significant [16].

Park explored the effect of personalized playlists on agitation levels in adults with unspecified dementia [17]. Playlists composed of preferred music were administered 30 minutes before peak agitation times, in 30-minute sessions, twice a week for two weeks. The CohenMansfield Agitation Inventory (CMAI) was used to determine the peak agitation times as well as the agitation levels of the participants [17]. Agitation levels were found to significantly decrease throughout and after the music listening session compared to the baseline [17].

\section{Discussion}

The aim of this paper was to explore the impact of preferred music listening on cognitive performance and emotional arousal in individuals with dementia. The results of this systematic review revealed consistent findings across previous studies that examined the beneficial effects of personalized music listening in individuals with dementia. Changes in factors such as mood, anxiety, and agitation were observed following personalized musical interventions.

Five of the studies from this systematic review demonstrated positive impacts of personalized music on mood. The study by Buller et al. reported increased happiness and improvements in overall mood in the majority of their participants [9]. Similarly, Murphy et al. saw improvements in mood and quality of life in participants following personalized playlists [10]. Furthermore, the intervention group in the study conducted by Sakamoto, Ando, and Tsutou demonstrated physiological changes (such as lower heart rates) which signified a more comfortable mood in participants [11] Reschke-Hernandez et al. demonstrated that familiar music associated with positive emotions can elicit lasting feelings of happiness, and Garrido et al. observed increased happiness following exposure to personalized playlists [12] [13]. As music listening is associated with enhanced mood, this may be an important intervention for individuals with dementia who commonly experience depression and apathy. Additionally, given that positive moods can help retain the functioning capacity in these individuals, interventions with personalized music may also help to maintain functional independence in people with dementia as well.

Preference-based musical interventions had impacts on negative dementia-associated behaviours and emotions, including BPSD. Individualized music listening showed positive effects on alleviating agitation in two studies. In the study conducted by Park, participants with unspecified dementia demonstrated a substantial decrease in agitation levels after listening to music [17]. This was similarly supported by another study that used a facial recognition software to analyze agitation in video recordings [15]. Personalized music listening was able to reduce agitation levels in only two of the four participants in the study; however, the study employed a very small sample size. Personalized music listening was demonstrated to decrease anxiety levels in individuals with dementia as shown by three studies $[9,11,16]$. In the first study, participants with dementia reported feeling less anxious after listening to their own music playlist [9]. The passive musical intervention group in the study by Sakamoto, Ando and Tsutou demonstrated shifts to more parasympathetic nerve activity which resulted in decreased anxiety levels as well [11]. These results were also consistent with another study that measured anxiety using the RAID tool [16]. After listening to personalized music, participants scored lower anxiety scores compared to measurements taken prior to the intervention. It is evident that personalized musical listening can decrease negative behaviours and symptoms commonly associated with dementia. Thus, preferencebased music listening may improve the quality of life of these individuals by helping to relieve stress, agitation, aggression, and other BPSDs.

In addition to the improvements in mood and affect demonstrated by these studies, personalized music can have an impact on cognitive function. In the context of the arousal-and-mood hypothesis, listening to music can elevate mood and improve motivation, thereby enhancing performance on cognitive tasks [6]. This theory suggests that the increased happiness and decreased anxiety as well as agitation seen throughout this review can potentially lead to better performance on cognitive tasks. As personalized music has shown to impact emotional affect in individuals with dementia, it can be further hypothesized that there may be improvements in cognitive performance following preference-based musical listening. For example, enhanced cognitive abilities were demonstrated in populations of healthy older adults after listening to autobiographicallysalient music [18]. Another study in the review also demonstrated a retention in cognitive performance in individuals with dementia after listening to personalized music [14]. This research is important given the need for individualized cognitive interventions for those with neurodegenerative conditions.

Overall, the use of personalized playlists for music listening in individuals with dementia has demonstrated various benefits such as improved mood and decreased agitation and anxiety. While formal music therapy programs may be costly and inconvenient for some, personalized playlists provide an accessible method of improving quality of life, and possibly cognitive functioning in those with dementia. This intervention can be used in both clinical and at-home settings; as caregivers have the ability to create personalized playlists, this 
UNDERGRADUATE RESEARCH IN NATURAL AND CLINICAL SCIENCE AND TECHNOLOGY (URNCST) JOURNAL Read more URNCST Journal articles and submit your own today at: https://www.urncst.com

intervention can be delivered in a familiar setting and in a cost-effective manner.

According to the review, the interventions in the literature consisted of personalized playlists that were compiled using feedback from caregivers, family members, as well as the participants themselves. The lengths of the interventions used varied among studies, with some studies conducting 4-minute interventions, while others conducted 60-minute interventions. The frequencies of the interventions were heterogeneous across studies as well, ranging from once per week to five times per week. It is evident that the methods used to deliver the personalized musical interventions are inconsistent, which makes it difficult to determine the optimal length and frequency of intervention delivery that promotes the most favourable outcomes. This demonstrates the need for more detailed and standardized guidelines for the use of personalized musical interventions for individuals with dementia.

The limitations of this review include the restricted number of databases explored as well as the small number of studies that met the inclusion criteria. This limited amount of literature was expected given the specificity of the field of interest. In addition, the participants included in these studies varied in the severity and diagnosis of dementia subtype, thus limiting the generalizability of the results from this review. Furthermore, methods used to implement personalized musical interventions were heterogeneous; thus it was difficult to extract a conclusive, quantitative consensus of the findings.

\section{Conclusions}

This systematic review demonstrates the beneficial outcomes of personalized playlists in the lives of individuals with dementia. The included studies showed that preferred music listening can elicit improvements in overall mood and decreases in BPSD such as agitation and anxiety. However, inconsistent methodology surrounding the delivery of personalized musical playlists to individuals with dementia is concerning as this demonstrates a need for greater support for people with dementia and caregivers. Therefore, future studies can investigate optimal parameters of preference-based musical interventions, such as optimizing the frequency and length of the intervention. Furthermore, little research has investigated the potential of preference-based music listening that can be implemented by loved ones rather than relying on health care professionals. Thus, future research should investigate the accessibility of personalized music listening compared to traditional music interventions, as well as the impacts it can have on functional independence.

\section{List of Abbreviations Used}

AD: Alzheimer's disease

BPSD: behavioural and psychological symptoms in disorder

BEHAVE-AD: behavioural pathology in Alzheimer's

disease

TMCM: therapeutic music capacities model

MMSE: mini mental state examination

FACS: facial action coding system

RAID: rating anxiety in dementia

CMAI: Cohen-Mansfield agitation inventory

\section{Conflicts of Interest}

It is declared that there is no conflict of interest from all authors.

\section{Ethics Approval and/or Participant Consent}

As this was a literature review, consent from participants and approval from the research ethics board were not required to perform this study.

\section{Authors' Contributions}

$\mathrm{CE}$ : contributed to the collection of research articles, extraction and analysis of results, drafting and revision of the manuscript, and gave final approval for publication of the manuscript

MY: contributed to the collection of research articles, extraction and analysis of results, drafting and revision of the manuscript, and gave final approval for publication of the manuscript

\section{Acknowledgements}

We would like to express our sincere gratitude to Ricky Chow for his time and dedication in providing useful, constructive feedback throughout the reviewing and editing process.

\section{Funding}

No funding was used for this study.

\section{References}

[1] Dementia [Internet]. World Health Organization. [cited 2021 August 6]. Available from: https://www.who.int/ news-room/fact-sheets/detail/dementia

[2] Music and Dementia: An Overview [Internet]. Practical Neurology. [cited 2021 August 6]. Available from: https://practicalneurology.com/articles/2017june/music-and-dementia-an-overview

[3] Baird A, Samson S. Music and Dementia. Progress in brain research. Elsevier. 2015;217:207-235. https://doi.org/10.1016/bs.pbr.2014.11.028

[4] Music and Memories: The iPod Program [Internet]. Alzheimer Society. [cited 2021 August 6]. Available from: https://alzheimer.ca/greybruce/en/programsservices/music-memories\#What is the iPod_Program 
UNDERGRADUATE RESEARCH IN NATURAL AND CLINICAL SCIENCE AND TECHNOLOGY (URNCST) JOURNAL Read more URNCST Journal articles and submit your own today at: https://www.urncst.com

[5] Evaluation of the Alzheimer Society Toronto iPod project [Internet]. Toronto $(\mathrm{ON})$ : Balance of care research \& evaluation group. [cited 2021 August 6]. Available from: https://www.ryerson.ca/content/ dam/crncc/knowledge/relatedreports/balancecare/Evalu ationoftheAlzheimerSocietyTorontoIPodProject.pdf

[6] Thompson WF, Schellenberg EG, Husain G. Arousal, mood, and the Mozart effect. Psychology Science. 2001 May;12(3):248-51. http://doi.org/10.1111/14679280.00345

[7] Salimpoor VN, Benovoy M, Longo G, Cooperstock JR, Zatorre RJ. (2009). The rewarding aspects of music listening are related to degree of emotional arousal. Public Library of Science One. 2009 Oct 16;4(10). https://doi.org/10.1371/journal.pone.0007487

[8] Brancatisano O, Baird A, Thompson, WF. Why is music therapeutic for neurological disorders? The therapeutic music capacities model. Neuroscience Biobehavioral Reviews. 2020 May;112:600-615. https://doi.org/10.1016/j.neubiorev.2020.02.008

[9] Buller E, Martin PK, Stabler A, Tucker B, Smith J, Norton L, Schroeder RW. The Roth project - Music and memory: A community agency initiated individualized music intervention for people with dementia. Kansas Journal of Medicine. 2019 Nov 25;12(4):136-140. Available from: https://www.ncbi.nlm.nih.gov/pmc/ articles/PMC6884019/

[10] Murphy K, Liu WW, Goltz D, Fixsen E, Kirchner S, $\mathrm{Hu}$ J, White H. Implementation of personalized music listening for assisted living residents with dementia. Geriatric Nursing. 2018 Oct;39(5):560-565. http://doi.org/10.1016/j.gerinurse.2018.04.001

[11] Sakamoto M, Ando H, Tsutou A. Comparing the effects of different individualized music interventions for elderly individuals with severe dementia. International Psychogeriatrics. 2013 May;25(5):77584. http://doi.org/10.1017/S1041610212002256
[12] Reschke-Hernández AE, Belfi AM, Guzmán-Vélez E, Tranel D. Hooked on a feeling: Influence of brief exposure to familiar music on feelings of emotion in individuals with Alzheimer's disease. Journal of Alzheimer's Disease. 2020 Nov 24;78(3):1019-1031. http://doi.org/10.3233/JAD-200889

[13] Garrido S, Stevens CJ, Chang E, Dunne L, Perz J. Music and dementia: Individual differences in response to personalized playlists. Journal of Alzheimer's Disease. 2018 July 3;64(3):933-941. http://doi.org/ 10.3233/JAD-180084.

[14] Pérez-Ros P, Cubero-Plazas L, Mejías-Serrano T, Cunha C, Martínez-Arnau FM. Preferred music listening intervention in nursing home residents with cognitive impairment: A randomized intervention study. Journal of Alzheimer's Disease. 2019; 70(2):433-442. http://doi.org/10.3233/JAD-190361

[15] Ragneskog H, Asplund K, Kihlgren M, Norberg A. Individualized music played for agitated patients with dementia: Analysis of video-recorded sessions. International Journal of Nursing Practices. 2001 Jun;7(3):146-55. http://doi.org/10.1046/j.1440-172x $.2001 .00254 . x$

[16] Sung HC, Chang AM, Lee WL. A preferred music listening intervention to reduce anxiety in older adults with dementia in nursing homes. Journal of Clinical Nursing. 2010 Apr;19(7-8):1056-64. http://doi.org/ 10.1111/j.1365-2702.2009.03016.x

[17] Park H. Effect of music on pain for home-dwelling persons with dementia. Pain Management Nursing. 2010 Sep;11(3):141-7. http://doi.org/10.1016/ j.pmn.2009.05.004

[18] Chow R, Noly-Gandon A, Moussard A, Ryan JD, Alain C. Effects of transcranial direct current stimulation combined with listening to preferred music on memory in older adults. Scientific Reports. 2021 Jun 16;11(1):12638. http://doi.org/10.1038/s41598$\underline{021-91977-8}$

\author{
Article Information \\ Managing Editor: Jeremy Y. Ng \\ Peer Reviewers: Ricky Chow, Bi-ru Amy Yeung \\ Article Dates: Received Aug 07 21; Accepted Oct 14 21; Published Nov 1021
}

\title{
Citation
}

Please cite this article as follows:

Ellewela CN, Yuen M. The effects of personalized music listening on older adults with dementia: A literature review.

URNCST Journal. 2021 Nov 10: 5(10). https://urncst.com/index.php/urncst/article/view/310

DOI Link: https://doi.org/10.26685/urncst.310 
UNDERGRADUATE RESEARCH IN NATURAL AND CLINICAL SCIENCE AND TECHNOLOGY (URNCST) JOURNAL

Read more URNCST Journal articles and submit your own today at: https://www.urncst.com

\section{Copyright}

(C) Chethana N. Ellewela, Monica Yuen. (2021). Published first in the Undergraduate Research in Natural and Clinical Science and Technology (URNCST) Journal. This is an open access article distributed under the terms of the Creative Commons Attribution License (https://creativecommons.org/licenses/by/4.0/), which permits unrestricted use, distribution, and reproduction in any medium, provided the original work, first published in the Undergraduate Research in Natural and Clinical Science and Technology (URNCST) Journal, is properly cited. The complete bibliographic information, a link to the original publication on http://www.urncst.com, as well as this copyright and license information must be included.

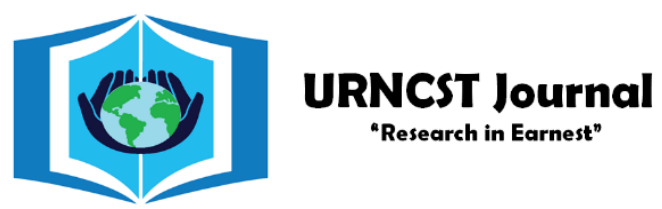

\section{Funded by the \\ Government of Canada}

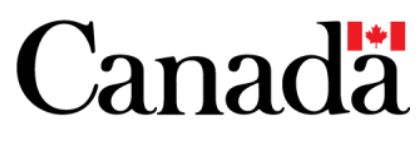

Do you research in earnest? Submit your next undergraduate research article to the URNCST Journal!

| Open Access | Peer-Reviewed | Rapid Turnaround Time | International | | Broad and Multidisciplinary | Indexed | Innovative | Social Media Promoted |

Pre-submission inquiries? Send us an email at info@ urncst.com| Facebook, Twitter and LinkedIn: @URNCST

Submit YOUR manuscript today at https://www.urncst.com! 